\title{
Clinical Significance of Peripheral Blood T Lymphocyte Subsets in Helicobacter pylori-Infected Patients
}

\author{
Yuka Satoh, ${ }^{1}$ Hatsue Ogawara, ${ }^{1}$ Osamu Kawamura, ${ }^{2}$ \\ Motoyasu Kusano, ${ }^{3}$ and Hirokazu Murakami' ${ }^{1}$ \\ ${ }^{1}$ Department of Laboratory Sciences, Course of Health Sciences, Gunma Graduate School of Health Sciences, Showa-machi 3-39-22, \\ Maebasi 371-8514, Gunma, Japan \\ ${ }^{2}$ Department of Medicine and Molecular Science, Gunma University Graduate School of Medicine, Showa-machi 3-39-22, \\ Maebasi 371-8511, Gunma, Japan \\ ${ }^{3}$ Department of Endoscopy and Endoscopic Surgery, Gunma University Hospital Showa-machi 3-39-15, \\ Maebasi 371-8511, Gunma, Japan
}

Correspondence should be addressed to Hirokazu Murakami, hmura@gunma-u.ac.jp

Received 29 October 2011; Revised 17 December 2011; Accepted 22 December 2011

Academic Editor: D. Fan

Copyright (C) 2012 Yuka Satoh et al. This is an open access article distributed under the Creative Commons Attribution License, which permits unrestricted use, distribution, and reproduction in any medium, provided the original work is properly cited.

\begin{abstract}
Background. Helicobacter pylori chronically colonizes gastric/duodenal mucosa and induces gastroduodenal disease and vigorous humoral and cellular immune responses. Methods. In order to clarify the immunological changes induced by this infection, we determined the percentage and, as indicated, ratios of the following cells in peripheral blood of $45 \mathrm{H}$. pylori-infected patients and 21 control subjects: $\mathrm{CD} 4^{+} \mathrm{T}$ cell, CD8 ${ }^{+} \mathrm{T}$ cells, T helper 1 cells (Th1), T helper 2 cells (Th2), CD $4^{+} \mathrm{CD} 25^{+} \mathrm{T}$ cells, Foxp $3^{+}$regulatory $\mathrm{T}$ cells (Tregs), CD4/CD8 ratio, and Th1/Th2 ratio. Results. The percentage of CD8 ${ }^{+} \mathrm{T}$ cells was significantly lower in $H$. pyloriinfected patients (mean \pm SD; $18.0 \pm 7.1 \%$ ) compared to control subjects (mean \pm SD; 23.2 $\pm 7.8 \%)(P<0.05)$. The CD4/CD8 ratio was significantly higher in $H$. pylori-infected patients (mean $\pm \mathrm{SD} ; 3.1 \pm 2.4$ ) compared to control subjects (mean $\pm \mathrm{SD} ; 2.1 \pm 1.0$ ) $(P<0.05)$. The Th1/Th2 ratio was significantly lower in $H$. pylori-infected patients (mean $\pm \mathrm{SD} ; 10.0 \pm 8.5)$ compared to control subjects (mean $\pm \mathrm{SD} ; 14.5 \pm 9.0)(P<0.05)$. The percentage of $\mathrm{CD} 4{ }^{+} \mathrm{CD} 25^{+} \mathrm{T}$ cells in $H$. pylori-infected patients (mean $\pm \mathrm{SD}$; $13.2 \pm 6.2 \%$ ) was significantly higher than that in control subjects (mean $\pm \mathrm{SD} ; 9.8 \pm 3.4 \%)(P<0.05)$. However, there was no significant difference in Tregs. Conclusion. Tregs did not decrease, but the activation of humoral immunity and Th2 polarization were observed in the peripheral blood of $H$. pylori-infected patients. In some cases, these changes may induce systemic autoimmune diseases.
\end{abstract}

\section{Introduction}

Helicobacter pylori is a gram-negative, highly motile, and spiral-shaped bacterium, which is $2.5-3.5 \mu \mathrm{m}$ long and $0.5-$ $1.0 \mu \mathrm{m}$ in diameter and has one to six polar flagella at one end. $H$. pylori was discovered in intact areas of antral mucosa of human stomach [1]. The organism colonizes the non-acid-secreting mucosa of the stomach and the upper intestinal tract, including the duodenum. It survives in the acidic conditions of the stomach by generating ammonia from urea. The ammonia is believed to neutralize gastric acidity around the $H$. pylori. Person-to-person contact and ingestion of contaminated food or water are probable mechanisms for transmission of H. pylori [2].
Recent studies have revealed that $H$. pylori causes persistent infection in the human gastrointestinal tract and induces chronic gastritis, peptic ulcers, gastric cancer, and malignant lymphoma [3-5]. Furthermore, $H$. pylori was reported to induce vigorous humoral and cellular immune responses. White blood cell, neutrophil or lymphocyte counts were reported to increase in $H$. pylori-infected patients $[6,7]$. Conflicting data were reported on the percentages of $\mathrm{B}$ and $\mathrm{T}$ cell subsets in $H$. pylori-infected patients. One study reported no significant change in the percentages of B cell, CD4, CD8, or NK cell in peripheral blood lymphocytes $[8,9]$. On the other hand, Soares et al. reported increased peripheral blood CD4, activated CD4 and CD8 cells in H. pylori-infected patients [10]. 
H. pylori colonization of the gastric mucosa promotes severe local inflammation and induces recruitment of $\mathrm{CD} 4^{+}$ and $\mathrm{CD}^{+}$cells [11]. Th1 cells also accumulate in the gastric mucosa of $H$. pylori-infected patients and are reported to promote mucosal inflammation by secretion of IFN-gamma [12].

Regulatory T cells (Tregs) are nonproliferative and/or anergic in response to polyclonal stimulation but can suppress the proliferation and cytokine production of both $\mathrm{CD}^{+}$and $\mathrm{CD}^{+} \mathrm{T}$ cells via a cell-cell contact-dependent mechanism [13]. Their surface marker phenotype has been established as $\mathrm{CD} 4^{+} \mathrm{CD} 25^{+} \mathrm{Foxp}^{+}{ }^{+}[14]$. $H$. pylori colonizes gastric mucosa for an extended period despite the presence of a host immune system. Thus, it is hypothesized that the Tregs are involved in actively suppressing the host immune response. In fact, the number of Tregs in gastric mucosa of $H$. pylori-infected patients is significantly higher than in healthy controls [15-18].

In addition to gastrointestinal disease, $H$. pylor is associated with several autoimmune diseases, including idiopathic thrombocytopenic purpura (ITP), Sjögren syndrome, systemic sclerosis [19], Graves' disease [20], and autoimmune pancreatitis [21]. Given this association with autoimmune diseases, we hypothesized that $H$. pylori might induce systemic immunological changes. We, therefore, compared the following immune characteristics in peripheral blood of $H$. pylori-infected patients and control subjects: $\mathrm{CD} 4^{+}$ $\mathrm{T}$ cells, $\mathrm{CD}^{+} \mathrm{T}$ cells, ratio of CD4/CD8 cells, Th1 cells, Th2 cells, ratio of Th1/Th2 cells, $\mathrm{CD} 4{ }^{+} \mathrm{CD} 25^{+} \mathrm{T}$ cells, and $\mathrm{CD} 4^{+} \mathrm{CD} 25^{+} \mathrm{Foxp}^{+} \mathrm{T}$ cells.

\section{Patients and Methods}

2.1. Patients. This study was performed with approval from the Human Research Ethical Committee of Gunma University Hospital, and all patients and volunteers gave informed consent. Forty-five H. pylori-infected patients (32 male, 13 female) diagnosed at Gunma University Hospital between 2007 and 2010 were included in this study. The median age of the patients was 58 years (range, 22-81 years), and the male-female ratio was $32 / 13$. Infection by $H$. pylori was established by the following criteria: positive tests for urease and/or the biopsy sample of the stomach. Controls were obtained from $21 \mathrm{H}$. pylori-uninfected donors, who were negative for serum anti-H. pylori IgG antibody (Eiken Chemical Co., Ltd, Tokyo, Japan). The male/female ratio of controls was $1.1(11 / 10)$ and the median age was 36 years (range, 23-65 years). The clinical data for study subjects are shown in Table 1.

2.2. Measurement of CD4/CD8 Ratio. Peripheral blood cells were collected using EDTA-3 K. Lymphocytes were labeled using the following monoclonal antibodies: CD45-FITC/ CD4-RD1/CD8-ECD/CD3-PC5 (Cyto-Stat tetraCHROME monoclonal antibodies) and subsets were ana lyzed using an EPICS XL System II (Beckman Coulter, Fullerton, CA).

2.3. Measurement of Th1/Th2 Ratio. Whole heparinized blood was incubated at $37^{\circ} \mathrm{C}$ with $7 \% \mathrm{CO}_{2}$ for 4 hours with
TABLE 1: Characteristics of participants in this study.

\begin{tabular}{lcc}
\hline & Control & H. Pylori \\
\hline Cases $(n)$ & 21 & 45 \\
Sex $($ male: female) & $(9: 9)$ & $(32: 13)$ \\
Age median: range (year) & $36: 23-65^{*}$ & $58.0: 22-81^{*}$ \\
Hemoglobin $(\mathrm{g} / \mathrm{dl})$ & $13.7 \pm 1.2$ & $13.8 \pm 1.6$ \\
Hematocrit $(\%)$ & $41.4 \pm 4.0$ & $41.0 \pm 3.5$ \\
WBC $\left(\times 10^{9} / \mathrm{l}\right)$ & $5.7 \pm 1.5$ & $6.3 \pm 1.8$ \\
Neutrophils $\left(\times 10^{9} / \mathrm{l}\right)$ & $3.2 \pm 1.2$ & $3.8 \pm 1.4$ \\
Monocytes $\left(\times 10^{9} / \mathrm{l}\right)$ & $0.32 \pm 1.1$ & $0.35 \pm 1.1$ \\
Lymphocytes $\left(\times 10^{9} / \mathrm{l}\right)$ & $1.8 \pm 0.5$ & $1.8 \pm 0.5$ \\
Platelets $\left(\times 10^{9} / \mathrm{l}\right)$ & $233.9 \pm 55.4$ & $241.0 \pm 67.9$ \\
\hline
\end{tabular}

mean \pm SD $* P$ values $<0.05$.

$25 \mathrm{ng} / \mathrm{mL}$ phorbol 12-myristate 13-acetate (Sigma-Aldrich, St. Louis, MO), $1 \mu \mathrm{g} / \mathrm{mL}$ ionomycin, and $10 \mu \mathrm{g} / \mathrm{mL}$ Brefeldin A (Sigma-Aldrich, St. Louis, MO).

After treatment with FACS lysing solution and FACS permeabilizing solution (BD Biosciences, San Jose, CA), cells were stained at $4^{\circ} \mathrm{C}$ for $30 \mathrm{~min}$ with antihuman CD4PE-Cy5 (BD Pharmingen, San Jose, CA), FastImmune fluorescein isothiocyanate (FITC)-labeled antihuman IFN$\gamma$, and phycoerythrin- (PE-) labeled antihuman IL-4 (BD Biosciences, San Jose, CA). FastImmune IgG2a FITC/IgG1 $\mathrm{PE}$ isotype controls (BD Biosciences, San Jose, CA) were used as negative controls for human IFN- $\gamma$ and IL-4. Measurement of Th subsets was performed by 3-color flow cytometry as described below for Treg cells.

2.4. Treg Cell Measurements. PE-Cy5 antihuman CD4 monoclonal antibody (BD Pharmingen, San Diego, CA) and FITC antihuman CD25 (BD Biosciences, San Jose, CA) were used for surface antigen staining. Mouse IgG1, $\kappa$ FITC (BD Pharmingen) was used as an isotype control. PEconjugated antihuman Foxp3 (PCH101) and PE-conjugated rat IgG2a isotype control from eBiosciences (San Diego, CA) were used for intracellular Foxp3 staining according to the manufacturer's instructions. Tregs were defined as $\mathrm{CD} 4^{+} \mathrm{CD} 25^{+} \mathrm{Foxp}_{3}{ }^{+}$cells. Three-color flow cytometric analysis was performed on FACS Calibur flow cytometer using Cell Quest software (BD Biosciences, San Jose, CA).

2.5. Complete Blood Cell Count. Complete blood cell counts were performed using a total blood analyzer (ADVIA 120, Siemens, Tarrytown, NY).

2.6. Statistical Analysis. Data analysis was performed using SPSS statistics 17.0 (IBM, USA). Comparisons of quantitative data were performed using a nonparametric test (MannWhitney $U$ test). $P$ values $<0.05$ were considered significant.

\section{Results}

3.1. Patient Populations. The clinical data for study subjects is shown in Table 1. The median age was significantly higher in H. pylori-infected patient group compared to 


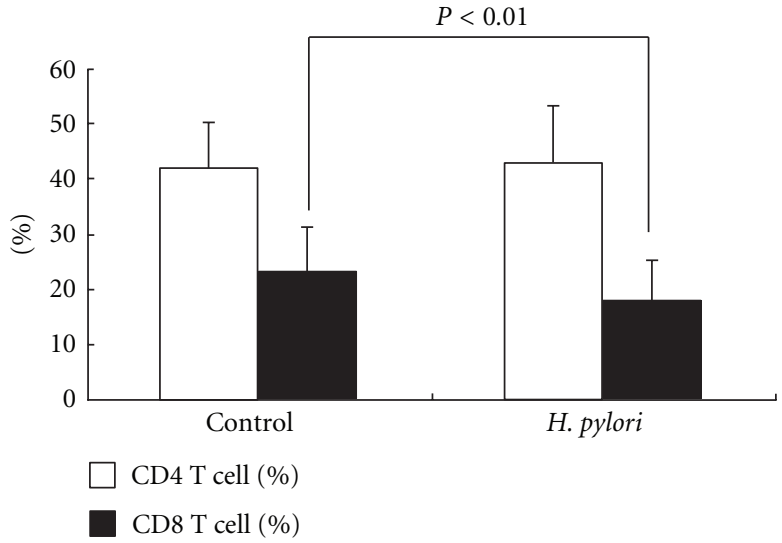

(a)

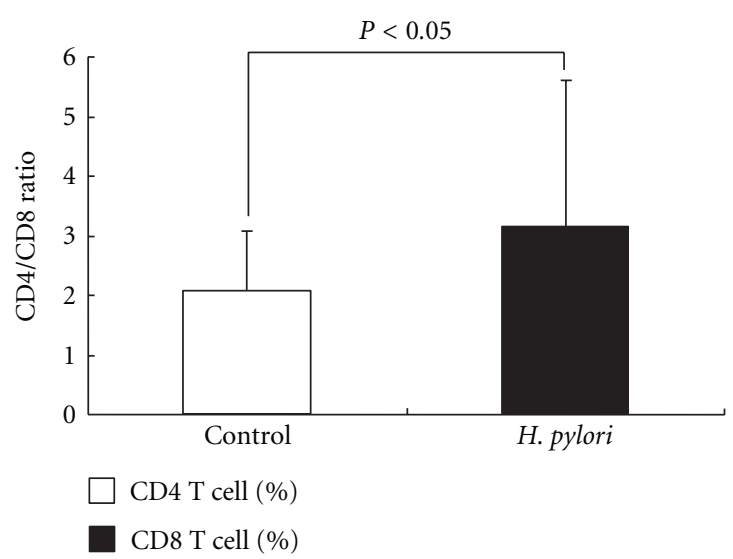

(b)

Figure 1: (a) Comparison of the percentage of $\mathrm{CD}^{+}$and $\mathrm{CD} 8^{+} \mathrm{T}$ cells. Left and right sides show the data of control subjects and $H$. pylori-infected patients, respectively. White columns represent the percentage of $\mathrm{CD} 4^{+} \mathrm{T}$ lymphocyte, and black columns represent $\mathrm{CD} 8^{+}$ T lymphocyte. Data are given as mean $\pm \mathrm{SD}$. There was no significant difference in the percentage of CD4 ${ }^{+} \mathrm{T}$ cells in $H$. pylori-infected patients (mean $\pm \mathrm{SD} ; 43.0 \pm 10.4 \%$ ) as compared to control subjects (mean $\pm \mathrm{SD} ; 42.2 \pm 8.1 \%$ ). However, the percentage of CD8 ${ }^{+} \mathrm{T}$ cells was significantly lower in $H$. pylori-infected patients (mean \pm SD; $18.0 \pm 7.1 \%$ ) compared to control subjects (mean \pm SD; $23.2 \pm 7.8 \%$ ) $(P<0.05)$. (b) CD4/CD8 ratio in control subjects (white column) and H. pylori-infected patients (black column). Data are given as mean \pm $\mathrm{SD}$. The CD4/CD8 ratio was significantly higher in $H$. pylori-infected patients (mean $\pm \mathrm{SD} ; 3.1 \pm 2.4$ ) compared to control subjects (mean $\pm \mathrm{SD} ; 2.1 \pm 1.0)(P<0.05)$.

the control group. However, there were no significant differences between the two groups in other items. White blood cell, neutrophil, monocyte, and lymphocyte counts were statistically identical in $H$. pylori-infected patients and control subjects.

\subsection{Percentage of $\mathrm{CD}^{+} \mathrm{T}$ Cells and $\mathrm{CD} 8^{+} \mathrm{T}$ Cells, and CD4/8} Ratio. Peripheral blood cells were labeled with CD4 and CD8 tags and analyzed by FACS. We found no significant difference in the percentage of $\mathrm{CD}^{+} \mathrm{T}$ cells in $\mathrm{H}$. pyloriinfected patients (mean $\pm \mathrm{SD} ; 43.0 \pm 10.4 \%$ ) as compared to control subjects (mean $\pm \mathrm{SD} ; 42.2 \pm 8.1 \%$ ). However, the percentage of $\mathrm{CD}^{+} \mathrm{T}$ cells was significantly lower in $H$. pylori-infected patients (mean $\pm \mathrm{SD} ; 18.0 \pm 7.1 \%$ ) compared to control subjects (mean $\pm \mathrm{SD} ; 23.2 \pm 7.8 \%)(P<0.05)$ (Figure 1(a)).

Reflecting the decrease in percentage of $\mathrm{CD}^{+}$cells, the CD4/CD8 ratio was significantly higher in $H$. pylori-infected patients (mean $\pm \mathrm{SD} ; 3.1 \pm 2.4$ ) compared to control subjects $($ mean $\pm \mathrm{SD} ; 2.1 \pm 1.0)(P<0.05)($ Figure $1(\mathrm{~b}))$.

\subsection{Percentage of Th1 and Th2 Cells, and Th1/Th2 Ratio.} Peripheral blood cells were stained for FACS analysis with markers for CD4 as well as intracellular stains for IFN- $\gamma$ and IL-4 to identify Th1 and Th2 cells, respectively. There was no significant difference in the percentage of Th1 cells in H. pylori-infected patients (mean $\pm \mathrm{SD} ; 20.2 \pm 8.6 \%$ ) and control subjects (mean $\pm \mathrm{SD} ; 21.2 \pm 10.6 \%$ ). However, the percentage of Th2 cells in $H$. pylori-infected patients (mean $\pm \mathrm{SD} ; 2.8 \pm 1.6 \%)$ was significantly higher than in control subjects (mean $\pm \mathrm{SD} ; 1.8 \pm 1.0 \%),(P<0.05)$ (Figure $2(\mathrm{a})$ ). Consistent with the increase in Th2 cells, the Th1/Th2 ratio was significantly lower in $H$. pylori-infected patients (mean $\pm \mathrm{SD} ; 10.0 \pm 8.5)$ compared to control subjects (mean $\pm \mathrm{SD}$; $14.5 \pm 9.0)(P<0.05)$ (Figure $2(\mathrm{~b}))$.

\subsection{Percentage CD4 $4^{+} \mathrm{CD} 25^{+}$and $\mathrm{CD}^{+} \mathrm{CD} 25^{+} \mathrm{Foxp}^{3^{+}} \mathrm{T}$ Cells.} The percentage of $\mathrm{CD} 4^{+} \mathrm{CD} 25^{+} \mathrm{T}$ cells in $H$. pylori-infected patients (mean $\pm \mathrm{SD} ; 13.2 \pm 6.2 \%$ ) was significantly higher than that in control subjects (mean $\pm \mathrm{SD} ; 9.8 \pm 3.4 \%$ ) $(P<0.05)$ (Figure 3). This cell population includes both activated $\mathrm{CD}^{+} \mathrm{T}$ cells and Tregs and thus changes in Tregs could be masked in this impure population. To measure the percentages of the Tregs, we monitored the frequency of $\mathrm{CD} 4^{+} \mathrm{CD} 25^{+}$Foxp $^{+} \mathrm{T}$ cells. The percentage of these Tregs was not significantly different between $H$. pylori-infected patients (mean $\pm \mathrm{SD} ; 4.1 \pm 2.1 \%$ ) and control subjects (mean $\pm \mathrm{SD} ; 4.0 \pm 1.7 \%)$ (Figure 3$)$.

3.5. The Difference of T Lymphocyte Subsets between Young and Old Subjects in the Control Group. Because the mean age of the control subjects was lower than that of the patient group, the control subjects were divided into 2 groups: $<40$ years old $(n=13)$ and $\geq 40$ years old $(n=8)$. When comparing the mean percentage of $\mathrm{T}$ lymphocyte subsets, there were no significant differences between the $<40$ group and the $\geq 40$ group (Table 2 ).

\section{Discussion}

Infection of the gastric mucosa with $H$. pylori is thought to occur in early childhood and to play a key role in the pathogenesis of many gastroduodenal diseases, including gastric ulcers, duodenal ulcers, gastric cancer, and gastric lymphoma. Previous studies have shown that $H$. pylori infection induces vigorous humoral and cellular immune 

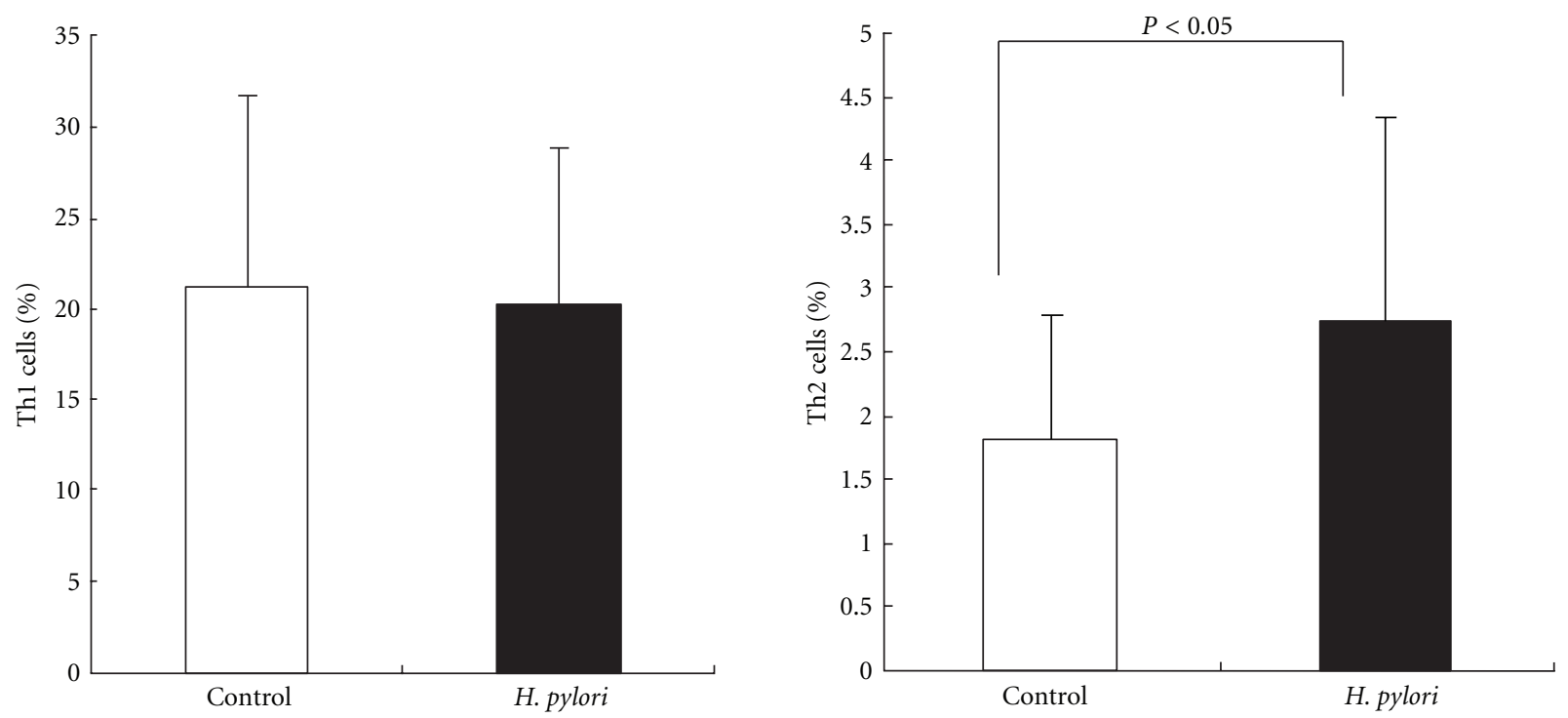

(a)

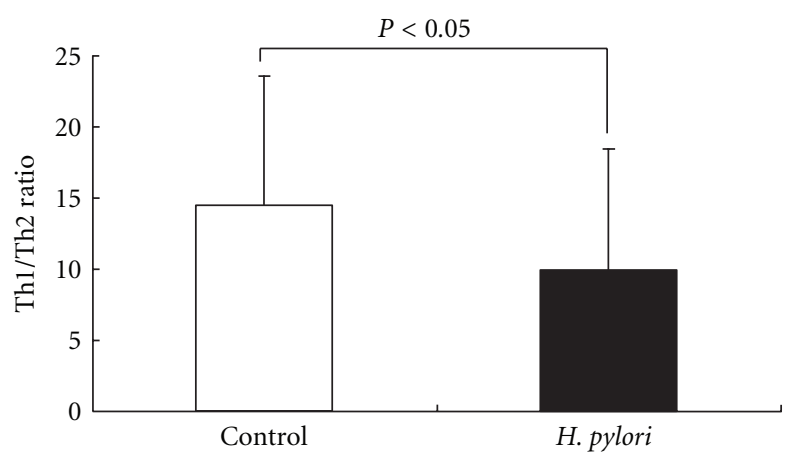

(b)

Figure 2: (a) The percentage of Th1 cells and Th2 cells. Left and right figures show the percentage of Th1 and Th2 cells, respectively. White columns represent the data of normal subjects, and black columns represent the data of $H$. pylori-infected patients. Data are given as mean \pm SD. There was no significant difference in the percentage of Th1 cells in $H$. pylori-infected patients (mean \pm SD; 20.2 $\pm 8.6 \%)$ and control subjects (mean \pm SD; $21.2 \pm 10.6 \%$ ). However, the percentage of Th2 cells in $H$. pylori-infected patients (mean \pm SD; $2.8 \pm 1.6 \%$ ) was significantly higher than in control subjects (mean $\pm \mathrm{SD} ; 1.8 \pm 1.0 \%),(P<0.05)$. (b) Comparison of Th1/Th2 ratio. White columns represent the data of normal subjects, and black columns represent the data of $H$. pylori-infected patients. Data are given as mean \pm SD. The Th1/Th2 ratio was significantly lower in $H$. pylori-infected patients (mean \pm SD; $10.0 \pm 8.5$ ) compared to control subjects (mean \pm SD; $14.5 \pm 9.0)(P<0.05)$.

responses. Kondo et al. reported that patients with $H$. pylori infection had increased neutrophile and monocyte counts in their peripheral blood [6]. Karttunen et al. also reported that white blood cell and lymphocyte counts were increased in $H$. pylori-infected patients [7]. In contrast, in our report, we found no significant difference in white blood cell, neutrophil, lymphocyte, and monocyte counts between $H$. pylori-infected patients and control subjects. Because $H$. pylori-infection induces chronic and local inflammation in gastric mucosa, it might not influence the absolute blood cell counts.

Yuceyar et al. reported no significant difference between $H$. pylori-infected patients and normal subjects in the peripheral lymphocyte profile, including T-, B-, CD4 ${ }^{+} \mathrm{T}-$, $\mathrm{CD}^{+} \mathrm{T}$ - and NK cells [9]. Conversely, the data presented here, show a decrease in the percentage of $\mathrm{CD}^{+} \mathrm{T}$ cells and an increase in the CD4/CD8 ratio in peripheral blood cells of $H$. pylori-infected patients. $\mathrm{CD}^{+} \mathrm{T}$ cells have also been reported to accumulate in the gastric mucosa and participate in the inflammatory process, promoting the severity of the disease $[22,23]$. These studies corroborate the findings of our study which suggests that the distribution of $\mathrm{CD}^{+} \mathrm{T}$ cells changes in $H$. pylori-infected patients, with peripheral $\mathrm{CD}^{+}$ $\mathrm{T}$ cells migrating into the gastric mucosa.

It is well known that $H$. pylori induces T-cell polarization towards a Th1-dominant response in gastric mucosa [24]. Moreover, D'Elios showed that H. pylori-specific Th1 cells could be cloned from $H$. pylori-infected gastric mucosa and that these cells were cytotoxic to gastric epithelial cells as they produced IFN- $\gamma$ [12]. However, few reports have been published to date characterizing the Th1/Th2 ratio in peripheral blood of $H$. pylori-infected patients. We find 


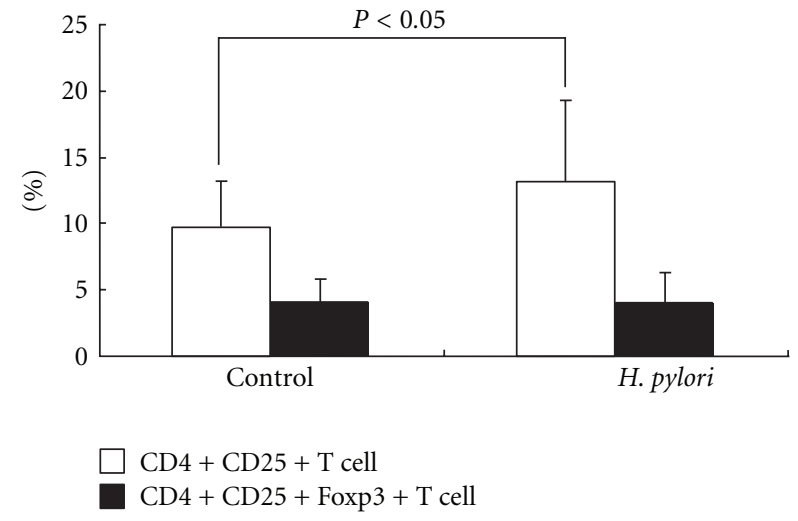

Figure 3: The percentage of $\mathrm{CD}^{+} \mathrm{CD} 25^{+} \mathrm{T}$ cell and $\mathrm{CD} 4^{+}$ $\mathrm{CD} 25^{+} \mathrm{Foxp}^{+}$(regulatory $\mathrm{T}$ cell). Left and right sides show the data of control subjects and $H$. pylori-infected patients, respectively. White columns represent the percentage of $\mathrm{CD} 4{ }^{+} \mathrm{CD} 25^{+} \mathrm{T}$ cell, and black columns represent the percentage of regulatory $\mathrm{T}$ cell. Data are given as mean \pm SD. The percentage of $\mathrm{CD} 4^{+} \mathrm{CD} 25^{+} \mathrm{T}$ cells in $H$. pylori-infected patients (mean $\pm \mathrm{SD} ; 13.2 \pm 6.2 \%$ ) was significantly higher than that in control subjects (mean $\pm \mathrm{SD} ; 9.8 \pm 3.4 \%)(P<$ $0.05)$. The percentage of Tregs $\left(\mathrm{CD} 4^{+} \mathrm{CD} 25^{+} \mathrm{Foxp} 3^{+} \mathrm{T}\right.$ cells) was not significantly different between $H$. pylori-infected patients (mean \pm $\mathrm{SD} ; 4.1 \pm 2.1 \%$ ) and control subjects (mean $\pm \mathrm{SD} ; 4.0 \pm 1.7 \%$ ).

TABle 2: The difference of T-lymphocyte subsets between young and old subjects in control group.

\begin{tabular}{lccc}
\hline & Age $<40$ & Age $\geq 40$ & $P$ values \\
\hline Cases $(n)$ & 13 & 8 & \\
CD4 T cells (\%) & $43.2 \pm 7.3$ & $40.7 \pm 9.4$ & 0.89 \\
CD8 T cells (\%) & $22.4 \pm 3.9$ & $24.4 \pm 12.1$ & 0.59 \\
CD4/CD8 ratio & $2.0 \pm 0.4$ & $2.3 \pm 1.6$ & 0.89 \\
Th1 cells (\%) & $19.1 \pm 10.1$ & $24.6 \pm 11.3$ & 0.096 \\
Th2 cells (\%) & $1.7 \pm 0.8$ & $2.0 \pm 1.2$ & 0.66 \\
Th1/Th2 ratio & $14.0 \pm 9.0$ & $15.2 \pm 9.6$ & 0.83 \\
CD4 ${ }^{+}$CD25 $5^{+}$T cells $(\%)$ & $9.7 \pm 3.6$ & $10.0 \pm 3.4$ & 0.66 \\
CD4 ${ }^{+}$CD25 ${ }^{+}$Foxp3 ${ }^{+} \mathrm{T}$ & $3.9 \pm 1.8$ & $4.3 \pm 1.5$ & 0.66 \\
cells $(\%)$ & & & \\
\hline
\end{tabular}

that the Th1/Th2 ratio in peripheral blood is significantly decreased in $H$. pylori-infected patients as compared to normal subjects. We hypothesize that, as suggested for the $\mathrm{CD} 8^{+}$ $\mathrm{T}$ cells, peripheral blood Th1 cells migrate to the gastric mucosa in $\mathrm{H}$. pylori-infected patients.

Age-related difference in Tregs has been described controversially [25]. Rosenkranz et al. reported that the frequency of Tregs $\left(\mathrm{CD}^{+} \mathrm{Foxp}^{+}\right)$increased with aging [26], and Gregg et al. also reported an increase in peripheral blood $\mathrm{CD} 4^{+} \mathrm{CD} 25$ high regulatory $\mathrm{T}$ cells associated with aging [27]. Conversely, others reported no correlation between the number of circulating $\mathrm{CD} 4^{+} \mathrm{CD} 25$ high Tregs and age [28]. In our study, we found that there was no statistical difference in the mean number of Tregs between $<40$-year-old and $>40$ year-old control subjects. Therefore, it was considered that the difference of age between control group and the patient group did not affect the evaluation of Tregs in H. pyloriinfected patients.

There was no report about the number/ratio of peripheral CD $4{ }^{+} \mathrm{CD} 25^{+} \mathrm{Foxp}^{+}$Tregs in $H$. pylori-infected patients. Lundgren et al. reported that $H$. pylori-infected patients have an impaired memory $\mathrm{CD} 4^{+} \mathrm{T}$ cell response to $H$. pylori that is linked to the presence of $H$. pylori-specific $\mathrm{CD} 4^{+} 25^{+} \mathrm{T}$ cells in peripheral blood, which actively suppress the response [29]. These authors also demonstrated the presence of Tregs that expressed the characteristic $\mathrm{CD} 4^{+} 25^{+}$ surface markers and coexpressed high levels of Foxp3 mRNA in the gastric mucosa [15]. In the data reported here the percentage of peripheral blood $\mathrm{CD} 4^{+} \mathrm{CD} 25^{+} \mathrm{T}$ cells, but not $\mathrm{CD} 4^{+} 25^{+} \mathrm{Foxp}^{+} \mathrm{T}$ cells, increased in $\mathrm{H}$. pylori-infected patients. Since $\mathrm{CD} 4^{+} \mathrm{CD} 25^{+} \mathrm{T}$ cells include Tregs as well as activated $\mathrm{T}$ cells, our data indicate that the percentage of Tregs did not increase in the peripheral blood of H. pyloriinfected patients.

Tregs did not decrease, but the activation of humoral immunity and Th2 polarization were observed in the peripheral blood of $H$. pylori-infected patients. In some cases, these changes may induce systemic autoimmune diseases.

\section{Conflict of Interests}

Authors have no conflict of interest to declare.

\section{Acknowledgment}

The authors thank the patients who agreed to participate in this study.

\section{References}

[1] B. J. Marshall and J. R. Warren, "Unidentified curved bacilli in the stomach of patients with gastritis and peptic ulceration," The Lancet, vol. 1, no. 8390, pp. 1311-1314, 1984.

[2] D. N. Taylor and M. J. Blaser, "The epidemiology of Helicobacter pylori infection," Epidemiologic Reviews, vol. 13, pp. 42-59, 1991.

[3] F. Megraud and H. Lamouliatte, "Helicobacter pylori and duodenal ulcer. Evidence suggesting causation," Digestive Diseases and Sciences, vol. 37, no. 5, pp. 769-772, 1992.

[4] J. Parsonnet, G. D. Friedman, D. P. Vandersteen et al., "Helicobacter pylori infection and the risk of gastric carcinoma," The New England Journal of Medicine, vol. 325, no. 16, pp. 11271131, 1991.

[5] J. Parsonnet, S. Hansen, L. Rodriguez et al., "Helicobacter pylori infection and gastric lymphoma," The New England Journal of Medicine, vol. 330, no. 18, pp. 1267-1271, 1994.

[6] Y. Kondo, T. Joh, M. Sasaki et al., "Helicobacter pylori eradication decreases blood neutrophil and monocyte counts," Alimentary Pharmacology and Therapeutics, Supplement, vol. 20, no. 1, supplement, pp. 74-79, 2004.

[7] T. J. Karttunen, S. Niemelä, and T. Kerola, "Blood leukocyte differential in Helicobacter pylori infection," Digestive Diseases and Sciences, vol. 41, no. 7, pp. 1332-1336, 1996.

[8] B. Kayhan, M. Araslin, H. Eren et al., "Analysis of peripheral blood lymphocyte phenotypes and Th1/Th2 cytokines profile in the systemic immune responses of Helicobacter pylori 
infected individuals," Microbiology and Immunology, vol. 52, no. 11, pp. 531-538, 2008.

[9] H. Yuceyar, M. Saruc, A. Kokuludag, E. Terzioglu, G. Goksel, and A. Isisag, "The systemic cellular immune response in the Helicobacter pylori-associated duodenal ulcer and chronic antral gastritis," Hepato-Gastroenterology, vol. 49, no. 46, pp. 1177-1179, 2002.

[10] T. F. Soares, G. A. Rocha, A. M. C. Rocha et al., "Phenotypic study of peripheral blood lymphocytes and humoral immune response in Helicobacter pylori infection according to age," Scandinavian Journal of Immunology, vol. 62, no. 1, pp. 63-70, 2005.

[11] X. J. Fan, A. Chua, C. N. Shahi, J. McDevitt, P. W. N. Keeling, and D. Kelleher, "Gastric T lumphocyte responses to Helicobacter pylori in patients with H pylori colonisation," Gut, vol. 35, no. 10, pp. 1379-1384, 1994.

[12] M. M. D'Elios, M. Manghetti, F. Almerigogna et al., "Different cytokine profile and antigen-specificity repertoire in Helicobacter pylori-specific $\mathrm{T}$ cell clones from the antrum of chronic gastritis patients with or without peptic ulcer," European Journal of Immunology, vol. 27, no. 7, pp. 1751-1755, 1997.

[13] S. Sakaguchi, N. Sakaguchi, J. Shimizu et al., "Immunologic tolerance maintained by $\mathrm{CD} 25^{+} \mathrm{CD} 4^{+}$regulatory T cells: their common role in controlling autoimmunity, tumor immunity, and transplantation tolerance," Immunological Reviews, vol. 182, pp. 18-32, 2001.

[14] E. E. Winger and J. L. Reed, "Low circulating CD4 ${ }^{+}$ $\mathrm{CD} 25^{+} \mathrm{Foxp}^{+} \mathrm{T}$ regulatory cell levels predict miscarriage risk in newly pregnant women with a history of failure," American Journal of Reproductive Immunology, vol. 66, no. 4, pp. 320328, 2011.

[15] A. Lundgren, E. Strömberg, A. Sjoling et al., "Mucosal FOXP3expressing $\mathrm{CD}^{+} \mathrm{CD} 25$ high regulatory $\mathrm{T}$ cells in Helicobacter pylori-infected patients," Infection and Immunity, vol. 73, no. 1, pp. 523-531, 2005.

[16] G. Perrone, P. A. Ruffini, V. Catalano et al., "Intratumoural FOXP3-positive regulatory $\mathrm{T}$ cells are associated with adverse prognosis in radically resected gastric cancer," European Journal of Cancer, vol. 44, no. 13, pp. 1875-1882, 2008.

[17] B. Kindlund, A. Sjöling, M. Hansson et al., "FOXP3-expressing $\mathrm{CD}^{+}{ }^{+} \mathrm{T}$-cell numbers increase in areas of duodenal gastric metaplasia and are associated to $\mathrm{CD} 4^{+} \mathrm{T}$-cell aggregates in the duodenum of Helicobacter pylori-infected duodenal ulcer patients," Helicobacter, vol. 14, no. 3, pp. 192-201, 2009.

[18] T. Chen, R. Jin, Z. Huang, W. Hong, Z. Chen, and J. Wang, "The variation of expression of CD $4^{+} \mathrm{CD} 25^{+}$Foxp3 ${ }^{+}$ regulatory $\mathrm{T}$ cells in patients with Helicobacter pylori infection and eradication," Hepato-Gastroenterology, vol. 57, no. 99-100, pp. 430-435, 2010.

[19] M. Radić, D. M. Kaliterna, and J. Radić, "Helicobacter pylori infection and systemic sclerosis-is there a link?" Joint Bone Spine, vol. 78, no. 4, pp. 337-340, 2011.

[20] V. Bassi, C. Santinelli, A. Iengo, and C. Romano, "Identification of a Correlation between Helicobacter pylori Infection and Graves' Disease," Helicobacter, vol. 15, no. 6, pp. 558-562, 2010.

[21] R. Jesnowski, B. Isaksson, C. Möhrcke et al., "Helicobacter pylori in autoimmune pancreatitis and pancreatic carcinoma," Pancreatology, vol. 10, no. 4, pp. 462-466, 2010.

[22] C. J. Hood and M. Lesna, "Immunocytochemical quantitation of inflammatory cells associated with Helicobacter pylori infection," British Journal of Biomedical Science, vol. 50, no. 2, pp. 82-88, 1993.
[23] Z. Z. Nurgalieva, M. E. Conner, A. R. Opekun et al., "Bcell and T-cell immune responses to experimental Helicobacter pylori infection in humans," Infection and Immunity, vol. 73, no. 5, pp. 2999-3006, 2005.

[24] K. B. Bamford, X. Fan, S. E. Crowe et al., "Lymphocytes in the human gastric mucosa during Helicobacter pylori have a T helper cell 1 phenotype," Gastroenterology, vol. 114, no. 3, pp. 482-492, 1998.

[25] C. Dejaco, C. Duftner, and M. Schirmer, "Are regulatory Tcells linked with aging?" Experimental Gerontology, vol. 41, no. 4, pp. 339-345, 2006.

[26] D. Rosenkranz, S. Weyer, E. Tolosa et al., "Higher frequency of regulatory $\mathrm{T}$ cells in the elderly and increased suppressive activity in neurodegeneration," Journal of Neuroimmunology, vol. 188, no. 1-2, pp. 117-127, 2007.

[27] R. Gregg, C. M. Smith, F. J. Clark et al., "The number of human peripheral blood $\mathrm{CD} 4^{+} \mathrm{CD} 25$ high regulatory $\mathrm{T}$ cells increases with age," Clinical and Experimental Immunology, vol. 140, no. 3, pp. 540-546, 2005.

[28] C. Luther, S. Poeschel, M. Varga, A. Melms, and E. Tolosa, "Decreased frequency of intrathymic regulatory $\mathrm{T}$ cells in patients with myasthenia-associated thymoma," Journal of Neuroimmunology, vol. 164, no. 1-2, pp. 124-128, 2005.

[29] A. Lundgren, E. Suri-Payer, K. Enarsson, A. M. Svennerholm, and B. S. Lundin, "Helicobacter pylori-specific CD4 $4^{+}$ CD25high regulatory T cells suppress memory T-cell responses to H. pylori in infected individuals," Infection and Immunity, vol. 71, no. 4, pp. 1755-1762, 2003. 


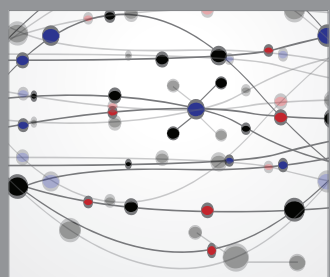

The Scientific World Journal
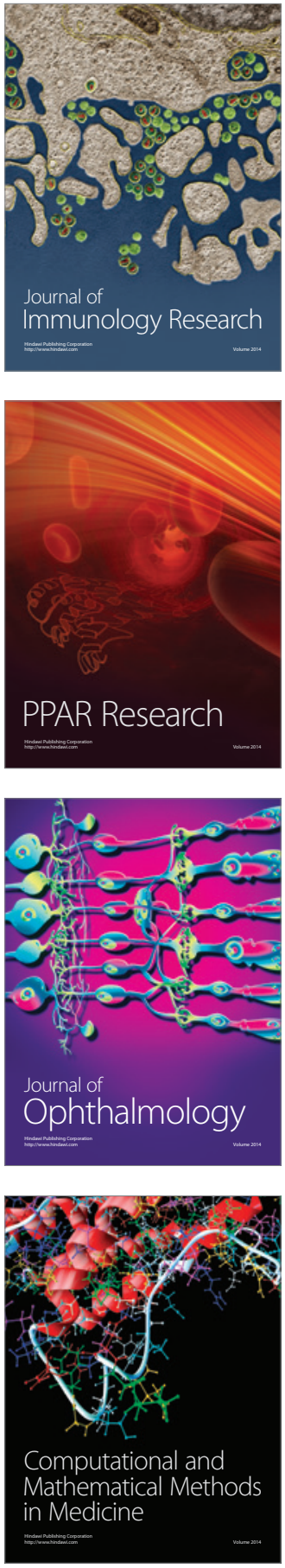

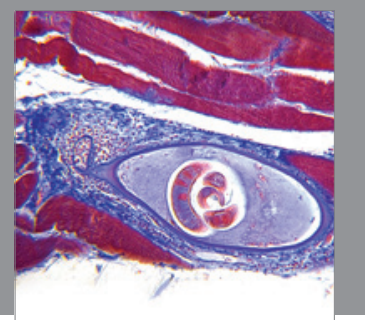

Gastroenterology

Research and Practice
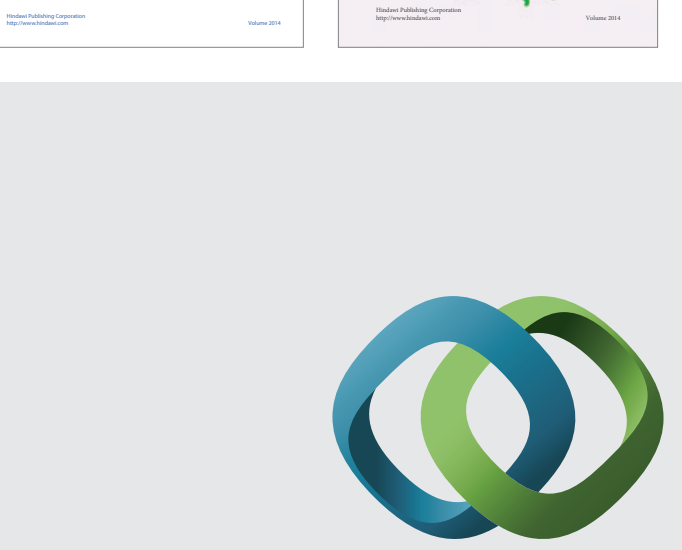

\section{Hindawi}

Submit your manuscripts at

http://www.hindawi.com
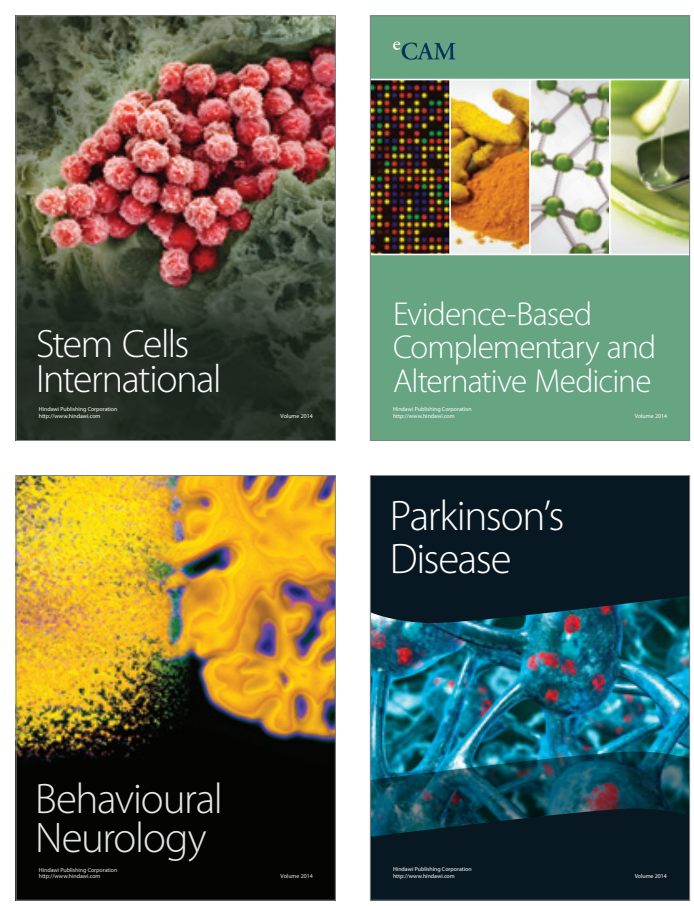

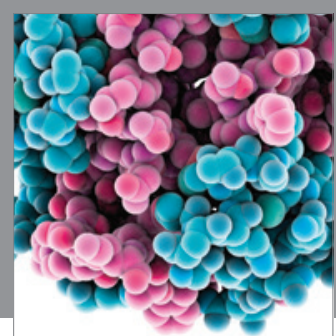

Journal of
Diabetes Research

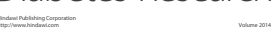

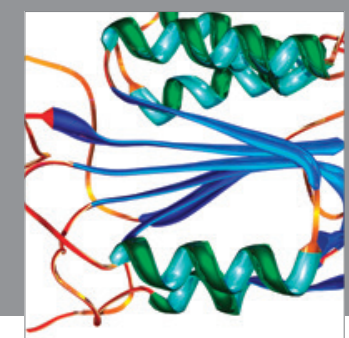

Disease Markers
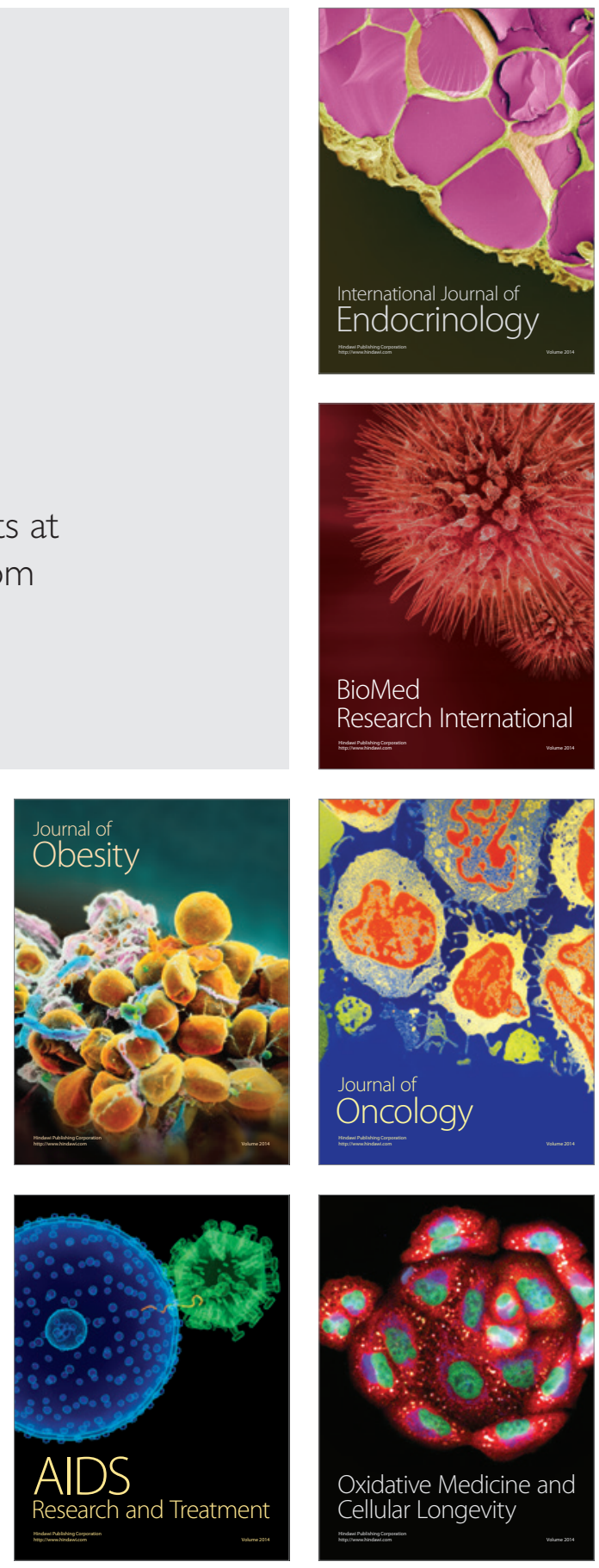